\title{
Candi Dan Konteksnya: Tinjauan Arkeologi-Ruang
}

\author{
Nurhadi Rangkuti
}

Keywords: space, spatial, stone material, temple, Hindu-Buddha, source material

\section{How to Cite:}

Rangkuti, N. Candi Dan Konteksnya: Tinjauan Arkeologi-Ruang. Berkala Arkeologi, 15(3), 37-42. https://doi.org/10.30883/jba.v15i3.668

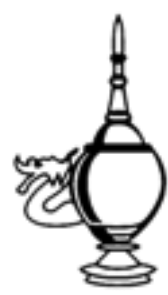

\section{Berkala Arkeologi}

https://berkalaarkeologi.kemdikbud.go.id/

Volume 15 No. 3, 1995, 37-42

DOI: $10.30883 /$ jba.v15i3.668

\section{cc) (1) (9)}

This work is licensed under a Creative Commons Attribution-NonCommercialShareAlike 4.0 International License. 


\title{
CANDI DAN KONTEKSNYA: TINJAUAN ARKEOLOGI-RUANG
}

\author{
Nurhadi Rangkuti \\ (Balai Arkeologi Yogyakarta)
}

\section{Pendahuluan}

Candi', merupakan archaeological record berupa budaya bendawi masa lalu yang bisu. la tidak dapat berbicara tentang fungsi, arti dan simbol yang dikandungnya. Adalah tugas para ahli arkeologi membuat data arkeologi ter-sebut bicara tentang zamannya. Akan tetapi para ahli arkologi pada umumnya menghadapi ken-dala, yaitu adanya jarak waktu dan "jarak buda-ya" untuk memahami dan menterjemahkan sisa-sisa perilaku manusia masa lalu yang terfosil da-lam bentuk artefak. Masalah inilah yang terus menerus menjadi debat panjang arkeologi dunia. Berbagai teori, pendekatan dan metode analisis tełah dikembangkan untuk mendekatkan persep-si subyek (peneliti) dengan obyek (budaya masa lalu) yang diterjemahkannya. Para ahli arkeologi di Indonesia juga menghadapi masalah yang sa-ma dalam menjelaskan dan menterjemahkan gagasan, simbol, sistem, teknologi dan adaptasi manusia masa lalu dari archaeological records.

Penelitian candi di indonesia telah dilakukan sejak abad ke-19, oleh Sir Thomas Raffles (1817) yang mempublikasikan karyanya; History of Java. Setelah itu banyak penelitian saling melengkapi dalam membeberkan rahasia candi, seperti penelitian yang dilakukan Bosch, Krom, Stutterheim, AJ. Bernett Kempers, Soekmono, Boecha-ri, Mundardjito, dan Noerhadi Magetsari. Pada hakekatnya mereka berusaha menjelaskan latar belakang budaya, sejarah, dan menterjemahkan muatan simbolik candi, dengan cara menginterpretasikan konteks candi dari berbagai dimensi yang melingkunginya.

Tulisan ini akan mengulas ringkas beberapa pendekatan dan metode analisis kontekstual yang digunakan para peneliti terdahulu dalam menafsirkan arti, fungsi dan simbol candi. Lebih khusus lagi pembahasan dititikberatkan pada konteks candi dalam dimensi ruang.

\section{Konteks Dalam Arkeologi}

Kata konteks atau kontekstual (contextual), berasal dari bahasa latin, contexere, yang berarti:

\footnotetext{
${ }^{1}$ Candi, sebutan untuk seluruh monumen dari bahan ba-tu dan bata berupa kuil, pemandian, gapura, pening-galan masa Hindu-Buda dari abad ke-5 hingga $15 \mathrm{M}$.
}

"merangkai, menyusun, gabung bersama, menghubungkan" (Butzer, 1982; lan Hodder, 1986). Dalam arkeologi, analisis kontekstual terhadap archaeological record telah dimulai, ketika Walter W.Taylor dalam tahun 1948 mengemukakan pendekatan konjungtif (conjunctive appro-ach) dalam arkeologi. Artefak difahami sebagai benda materi dalam sistem perilaku budaya masyarakat, sehingga perhatian arkeolog terpusat pada kajian terhadap konteks arkeologi untuk mencapai kesimpulan fungsional. Pendekatan ini dapat mengungkapkan sistem budayanya secara keseluruhan (Mundardjito 1993a:6-7).

Dalam setiap ekskavasi, para arkeolog sering meninggalkan asosiasi dan konteks artefak dalam lapisan tanah, karena sibuk dengan klasifikasi artefak. Lewis R. Binford, seorang tokoh Arkeologi Pem-baharuan (New Archaeology ${ }^{2}$ ) tahun 1960-an, menekankan pandangan sistemik (systemic view of culture). Pandangannya beranggapan bahwa kebudayaan adalah kompleks, sistemik, terintegrasi, adaptif, ekstrasomatik dan materialistik yang didasari oleh organisasi ting-kah laku manusia (Gibbon 1989:70). Sistem bu-daya terdiri dari sejumlah sub sistem yang saling berhubungan dalam konteks teknologi, sosial dan ideologi. Fungsi budaya bendawi masa lalu dilatari, oleh konteks tersebut.

Schiffer (1976) menguraikan proses panjang suatu artefak dari konteks sistemnya ke konteks arkeologi. Proses tersebut menuntut arkeolog berhati-hati dalam menafsirkan archaeological records, sehubungan rekonstruksi sistem budaya. Budaya bendawi masa lalu yang sampai di tangan para arkeolog telah rusak dan tidak utuh lagi karena telah mengalami transformasi, se-hingga pola yang terdapat pada suatu himpunan artefak, belum tentu menggambarkan pola peri-laku manusia dalam sistem budaya masa lalu.

Ian Hodder, salah seorang tokoh postprocessual archaeology, menafsirkan suatu fenomena arkeologi dalam konteks yang luas. Konteks budaya bendawi meliputi lingkungan, teknologi, dan tindakan, serta.konteks sebagai suatu "teks"

\footnotetext{
2 Label New Archaeology pertama kali digunakan oleh Joseph Caldwell tahun 1959 untuk menandai pendekat-an-pendekatan dari era baru arkeologi di Amerika Uta-ra, dalam bukunya:The New American Archaeology (Gibbon 1989).
} 
atau wacana yang dapat dibaca (Hodder 1986; Tanudirjo 1993:11-12). Suatu wacana hanya dapat dibaca dengan benar jika kita mampu

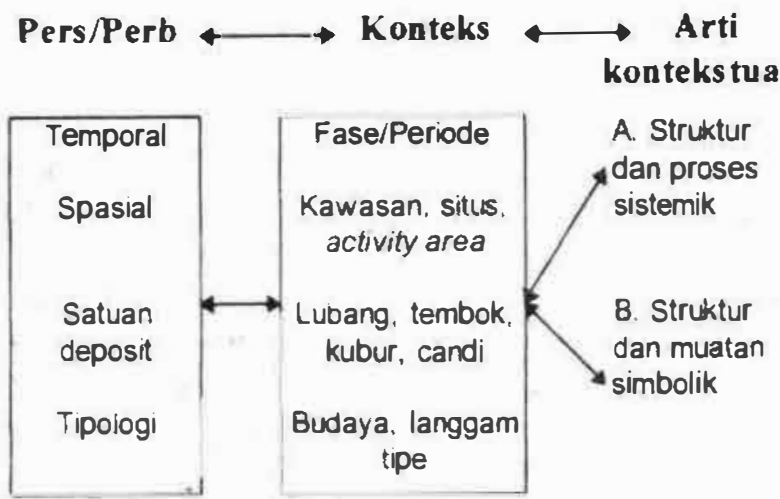

Bagan interpretasi arti kontekstual dari perbedaaan dan persamaan antara objek-objek arkeologi (Sum-ber Ian Hodder 1986:125)

memahami "bahasa"nya. Pemahaman arti suatu aspek budaya secara internal dan emik (Tanudirjo 1993:12). Akan tetapi tidak ada tata bahasa dan kamus dalam "bahasa" budaya bendawi, sebagaimana dalam bahasa tertulis. Untuk itu diperlukan metodologi dalam menjabarkan budaya bendawi masa lalu. lan Hodder (1986) menekankan pentingnya data kontekstual. Konteks ditentukan dengan mengidentifikasi berbagai tipe persamaan dan perbedaan bermakna dari budaya bendawi didasarkan pada dimensi tipologi, depositional, ruang dan waktu. Berdasarkan hal tersebut dapat dibangun berbagai tipe asosiasi kontekstual. Selanjutnya dibuat abstraksi dari konteks, asosiasi, dan perbedaan, agar supaya sampai pada "arti" budaya dalam istilah fungsi dan isi. Konteks artefak adalah totalitas variasi dimensi yang relevan.

\section{Konteks Yang Terkandung Dalam Candi}

Soekmono dalam disertasinya: Candi, Fungsi dan Pengertiannya (1974) telah menafsirkan fungsi dan makna simbolik candi sebagai kuil, bukan sebagai makam. Kajiannya bertitik tolak dari archaeological record yaitu pripin $^{3}$, arca-arca,

${ }^{3}$ Pripih adalah peti batu biasanya ditanam dalam perigi candi dan kadang di bagian atap candi. Pripih berisi abu, pasir, dan relik-relik. Soekmono menganggap pripih merupakan inti dari suatu bangunan candi. Pripih sebelumnya dianggap peti abu jenasah yang ditanam dalam perigi candi. Dari 85 peripih candi yang dikumpulkan, tidak menunjukkan adanya sisa abu jenasah, dan hanya 6 pripih yang berasal dari perigi candi. Pripih tidak selalu di tanam dalam perigi tetapi tersimpan juga pada bagian-bagian lain candi bahkan atap candi, sehingga tidak ada hubungannya dengan pemakaman relief cerita (prasawya, pradaksina) ${ }^{4}$ berdasarkan penentuan arah pembacaan, arah hadap candi dan sifat keagamaan candi (Hindu dan Buddha). Perbedaan dan persamaan dari atribut-atribut candi tersebut mempunyai arti kontekstual yang berbeda. Penafsiran fungsi dan makna candi sebagai kuil dilakukan Soekmono dengan menggunakan analogi dari kesusasteraan-kesusasteraan Jawa Kuna dan prasasti-prasasti Jawa Kuna (Soekmono 1974)

Noerhadi Magetsari dalam disertasinya: Pemujaan Tathagata di Jawa Pada Abad X (1982), mengidentifikasi atribut-atribut candi yang relevan pada Candi Borobudur untuk memahami latar belakang agama dan filsafatnya. Candi Borobudur sebagai archaeological records ${ }^{5}$, bangunan berundak terdiri dari tingkatan yang berbeda-beda. ${ }^{6}$ Undak tersebut membentuk konfigurasi penempatan relief cerita dan patung-patung. Patung-patung ditempatkan pada relung-relung di atas pagar langkan menghadap ke empat penjuru mata angin, dan rangkaian cerita yang dipahatkan pada dinding lorong tingkatan berbentuk segi delapan, diidentifikasi sebagai variasi dimensi dari bentuk dan ruang yang bermakna untuk mengetahui latar belakang ajaran agama dan filsafat

4 Pembacaan relief-relief cerita dari kiri ke kanan (pra. sawya) dan dari kanan ke kiri (pradaksina) ditafsirkan mempunyai makna simbolik. Pradaksina dalam agama Hindu adalah penghormatan kepada dewa dan karenanya berkenaan dengan upacara pemujaan (dewayajna), sedangkan prasawya adalah penghor-matan terhadap nenek moyang dan karenanya berta-lian dengan upacara kematian (pitryajna) (Soekmono 1974:60). Candi-candi yang mempunyai relief cerita dengan pembacaan dua macam (prasawya dan pra-daksina) ditafsirkan bahwa bangunan-bangunan suci itu untuk memuja serta menghormati dewa dan raja almarhum.

${ }^{5}$ Pengertian archaeological records telah diuraikan secara panjang lebar oleh Noerhadi Magetsari (1995). Archaeological records merupakan rekaman historical facts (kebudayaan sebagai "fact" yang telah punah), yaitu kebudayaan materi yang pada hakekatnya adalah wujud ide, gagasan atau kepercayaan pen-ciptanya

${ }^{6}$ Tingkatan pertama terdiri dari tingkatan-tingkatan segi delapan, yang kemudian diikuti oleh tingkatan yang agak lonjong di mana beberapa stupa didirikan di setiap tingkatannya, untuk kemudian ditutup dengan se-buah stupa besar sebagai tingkatan puncak Pada tingkatan yang berbentuk segi delapan, pada sisinya didirikan pagar langkan sehingga membentuk lorong. Di kedua dinding lorong ini dihiasi dengan relief Kar-mawibhangga pada tingkatan paling bawah, berturut-turut ke atas dihiasi relief Lalitavistara. Jatakamala, dan Gandavyuha, khususnya Bha-dracari (Noerhadi Magetsari 1995:13). 
yang terkandung pada bangunan Candi Borobudur. Noerhadi Magetsari melakukan analisis analogi relasional ${ }^{7}$ dengan historical records untuk menjangkau emiknya.

Historical records digunakan arkeologi sejarah untuk mengetahui latar belakang kepercayaan dalam hubungannya dengan pola-pola yang dideskripsikan sebagai data arkeologi (Noehadi Magetsari,1995:12). Teks agama dipilih sesuai dengan ajaran agama yang melatari Candi Borobudur. Dari hasil analogi relasional antara observasi bentuk dengan teks Agama Buddha, dapat dikenali bahwa patung-patung yang ditempatkan pada relung-relung candi itu adalah Tataghata, terdiri dari Amithaba, Aksobhya, Ratnasambhava, Amoghasiddhi, masing-masing menghadap ke arah satu mata angin. Pada tingkatan yang berbentuk lonjong di dalam stupa berongga terdapat patung Vairocana menghadap ke semua mata angin. Dari rangkaian cerita yang dipahatkan, dapat diketahui bahwa seluruh struktur bangunan melambangkan ajaran Mahayana. Selanjutnya melalui pengenalan Tathagata yang dipahatkan diketahui bahwa struktur Candi Borobudur melambangkan Vajrayana. Dari tokoh-tokoh yang dipahatkan diketahui Vajrayana aliran Guhyasamajatantra (Noerhadi Magetsari 1995:13-14).

\section{Konteks Candi Dalam Dimensi Ruang}

Salah satu cara untuk menganalisis data kontekstual adalah studi arkeologi-ruang (spatial archaeology). Studi ini mempelajari sebaran dan hubungan keruangan pada aneka jenis pusat aktivitas manusia dalam skala mikro, semi-mikro (meso) dan makro (Mundardjito 1993). Arkeologi ruang memfokuskan pengkajian dimensi ruang (spatia), daripada pengkajian dimensi bentuk (formal) dan waktu (temporal). Mundardjito (1993b:4-5) menyatakan bahwa konsep dasar yang terkandung dalam definisi arkeologi-ruang timbul karena perkembangan arkeologi lambat laun menyadari bahwa data arkeologi tidak hanya diperoleh dari ciri-ciri yang terkandung dalam benda atau situs arkeologi itu sendiri, tetapi juga diperoleh dari hubungan keruangan antara benda-benda atau antara situs-situs arkeologi. Artefak tidak hanya dipandang sebagai obyek bagi kepentingannya sendiri, akan tetapi sebagai perantara (mediator) yang menghubungkan manusia dengan aspek-aspek lain seperti lingkungan. Studi ini memperlakukan benda arkeologi sebagai kumpulan atau himpunan dalam satuan ruang.

\footnotetext{
${ }^{7}$ Analogi relasional adalah sebuah analogi yang didasarkan atas interelasi prosesual dan struktural dari kebudayaan materi. Dimaksud di sini adalah analogi antara interrelasi struktural atau prosesual dari kebudayaan yang masih ada sekarang.
}

Pendekatan ekologi merupakan salah satu pendekatan dalam studi arkeologi-ruang yang mengamati konteks lingkungan. Arkeologi konteks dalam pendekatan ekologi, menurut Karl W. Butzer (1982) menitikberatkan pada ekspresi multidimensi dari keputusan yang diambil manusia dengan lingkungannya (Butzer 1982:7).

Di Indonesia, studi candi dalam konteks ruang telah dilakukan. WF. Stutterheim (1939) yang mempelajari pola tata letak Candi Borobudur dalam satuan lingkungan geografi Kali Elo dan Progo yang memiliki kemiripan pola tata letak stupa Bharhut dalam konteks lingkungan Sungai Gangga dan Yamuna di India '(Mundardjito 1993b). Bambang Budi Utomo (1992) telah mempelajari sebaran yoni (salah satu atribut candi) di daerah Kedu di Jawa Tengah. Penulis telah melakukan penelitian mengenai pemakaian bahan bangunan pada 29 situs candi yang tersebar di sekitar Prambanan (Kabupaten Sleman, DIY dan Kabupaten Klaten, Jawa Tengah) dalam kaitannya dengan pemanfaatan sumberdaya alam (Rangkuti 1984). Mundardjito (1993) dalam kajiannya menemukan konteks ekologi sebagai pertimbangan dalam penempatan 218 situs candi yang tersebar di Kabupaten Sleman dan Bantul, Daerah Istimewa Yogyakarta. Dua penelitian terakhir (Rangkuti 1984; Mundardjito 1993) menggunakan pendekatan ekologi untuk melihat konteks candi dengan lingkungannya

Mundardjito dalam disertasinya: "Pertimbangan ekologis dalam Penempatan Situs Masa Hindu-Buda di Daerah Istimewa Yogyakarta: Kajian Arkeologi-Ruang Skala Makro" pada tahun 1993, menggunakan pendekatan arkeologi-ekologi. Dalam penelitian ini hakekatnya Mundardjito ingin menterjemahkan secara "scientific" beberapa persyaratan dan aturan pembangunan candi yang tercantum dalam Kitab Manasara Silpasastra dan Silpa Prakarsa dari India. Kitab tersebut menyebutkan sebelum suatu bangunan kuil didirikan, terlebih dulu dikaji dan dinilai kondisi dan kemampuan lahan yang akan dijadikan tempat berdirinya bangunan suci. Dari kedua kitab itu disimpulkan bahwa pertimbangan potensi lahan dan air, ikut memainkan peranan penting dalam proses pengambilan keputusan yang dilakukan oieh para arsitek masa lalu berkenaan dengan pemilihan lokasi yang akan digunakan sebagai tempat berdirinya setiap bangunan yang bersifat keagamaan (Mundardjito 1993b:14). Dalam hal ini ada konteks antara sebaran candi dengan sebaran potensi sumberdaya lingkungan. Dengan

\& Arkeologi-ekologi mempelajari hubungan atau interaksi antara kebudayaan dan lingkungan. Dalam hal ini yang diamati adalah hubungan atau interaksinya. 
kata lain, pola sebaran situs candi sesuai dengan pola sebaran potensi sumberdaya alam.

Mundardjito menterjemahkan potensi gaib lahan tempat didirikannya bangunan suci yang tertulis dalam kitab-kitab Manasara Silpasastra dan Silpa Prakarsa, mengidentifkasi variabel-variabel lingkungan fisik yang dapat diamati dan diukur, yaitu variabel ketinggian tempat, kemiringan permukaan lahan, bentuklahan, jenis tanah, batuan, kedalaman efektif tanah, kedalaman muka air tanah, permeabilitas lapisan deposit air tanah (akifer), jarak terhadap sungai, dan jarak terhadap mata air. Kajian terhadap situs-situs candi dikhususkan dari segi keletakannya pada bentang lahan di wilayah penelitian, dengan menggunakan tingkat penelitian yang berstrategi makro Dalam kajian tingkat makro ini dikaji 218 situs candi di Kabupaten Sleman (181 situs candi) dan Kabupaten Bantul ( 37 situs candi).

Dalam analisis diamati pola hubungan situs dengan setiap variabel sumberdaya lingkungan dan pola hubungan situs dengan gabungan variabel sumberdaya lingkungan. Pengelompokan situs, pengelompokan variabel sumberdaya lingkungan dan pola hubungan situs dengan variabel sumberdaya lingkungan diidentifikasi dengan menggunakan metode statistik analisis. ${ }^{9}$ Hasil analisis menunjukkan terdapat empat macam pola hubungan antara keletakan situs-situs candi dengan variasi sumberdaya lingkungan. Hasil penelitian secara ringkas disimpulkan bahwa pertimbangan ekologi dalam penempatan situs-situs candi di daerah penelitian pada dasarnya sesuai dengan prinsip yang disebutkan dalam kitab India kuno Manasara Silpasastra dan Silpa Prakarsa. Namun ada pula sejumlah kecil situs ${ }^{10}$ yang tidak ditempatkan pada lahan berpotensi tinggi atau dengan kata lain kurang mempertimbangkan potensi ekologi yang tinggi dan tidak sesuai dengan aturan kitab India. Penempatan situs yang "menyimpang" itu juga tidak sesuai dengan konsep minimisasi enerji dan maksimisasi hasil kerja, yang menjadi dasar konsep dari pendekatan ekologi. Dalam hal ini Mundardjito memberikan peluang untuk menjawab masalah tersebut dengan

${ }^{9}$ Statistik analisis variabel-banyak (multivariate) correspondence analysis \& analisis tetangga terdekat.

${ }^{10}$ Situs-situs itu masuk dalam kelompok I, dikelompokkan berdasarkan tingkat potensi lahannya. Ada 7 situs dalam kelompok I, tersebar pada lahan yang mempunyai potensi lahan yang rendah, dilihat dari variabel jenis tanah, batuan, kelerengan, tanah, air tanah, dan jarak situs ke mata air. Hanya 2 variabel yang mempunyai potensi yang tinggi, yaitu jarak situs ke sungai dan ketinggian (Mundardjito, 1993b:228-232). cara pandang dan pendekatan lain selain model pendekatan ekologi yang digunakannya.

Dari uraian di atas tampak adanya pola yang tidak sesuai dengan prinsip ekologi, seiain itu terdapat juga pola pemakaian bahan bangunan candi. Sebagaimana telah disampaikan di depan penulis telah melakukan penelitian arkeologi-ruang skala makro di daerah yang sama, yaitu di Kabupaten Sleman, terutama di "kawasan" Prambanan (sejumlah kecil situs candi masuk wilayah Kabupaten Klaten, Jawa Tengah) untuk mengetahui hubungan antara sumberdaya alam dengan pola pemakaian bahan bangunan candi (Rangku-ti 1984). Pada umumnya cåndi-candi di daerah tersebut menggunakan batu andesit. Batu aglomerat (batu putih) digunakan pada beberapa unsur bangunan. Pemakaian batu tersebut oleh sebagian arkeolog (Krom 1923; Bernett Kempers 1952; Soediman 1976) menjadi dasar analisis kronologi candi-candi" .

Berdasarkan pengamatan terdapat pola pemakaian bahan bangunan candi pada 29 situs yang tersebar di dataran aluvial dan dataran tinggi Baturagung (daerah perbukitan Ratu Boko) Dataran tinggi tersebut merupakan sumber batuan aglomerat. Jenis batuan ini dimanfaatkan manusia masa lalu untuk bahan bangunan candicandi baik yang terdapat di dataran aluvial maupun di dataran Baturagung. Penelitian dilakukan dengan menggunakan pendekatan ekologi-budaya ${ }^{12}$ yang memperhatikan adanya hubungan antara budaya dan lingkungan satu ekosistem.

Untuk mengidentifkasi konteks antara penggunaan bahan candi dan sumberdaya alam, ditentukan atribut-atribut candi dari segi teknis-konstruksi bangunan, yaitu pondasi, batu isian dan batu kulit yang terdapat pada bangunan utama ${ }^{13}$,

${ }^{11}$ Candi-candi yang menggunakan batu aglomerat dibangun lebih belakangan dari candi-candi di sekitarnya yang tidak menggunakan bahan tersebut. Mereka hanya melihat pemakaian bahan aglomerat pada batu isian saja, tidak memperhatikan pemakaiannya pada bagian-bagian lain dari candi. Candi Loro Jonggrang, Plaosan, Sajiwan, dan Sambisari, yang ditemukan tahun 1966, dianggap dibangun lebih belakangan.

12 Ekologi-budaya (cultural-ecology) yang merupakan metodologi untuk menganalisis evolusi multilinear kebudayaan, pada intinya melihat perbedaan lingkungan akan mempengaruhi adaptasi teknologi manusia, selanjutnya mempengaruhi pula aspek-aspek bu-daya lainnya. . Ekologi budaya memusatkan perhatian pada aspek budaya yang erat berkaitan dengan pen-dayagunaan lingkungan, antara lain teknologi. Untuk lebih jelas lihat Julian $\mathrm{H}$. Steward (1955) dalam Theo-ry of Culture Change.

${ }^{13}$ Bangunan utama yang dimaksud di sini adalah bangunan induk dari satu gugusan candi, atau 
bangunan serta ${ }^{14}$, dan bangunan pagar/tembok keliling. Selain itu dipilih atribut candi bukan teknis-konstruksi bangunan, seperti arca, yoni, pripih, dan batu-batu candi (lepas). Sedangkan variabel lingkungan yang diamati adalah sumber batuan (geologi). Dalam kajian ini dipelajari hubungan antara variabel budaya (bahan atribut candi dan lokasi situs) dan variabel lingkungan (batuan dan lokasi sumber).

Hasil analisis diketahui bahwa sejumlah besar situs candi menggunakan bahan aglomerat, baik di dataran aluvial, maupun perbukitan Baturagung. Termasuk situs candi terjauh dari ruang sumber, yaitu Candi Sambisari yang mempunyai frekuensi pemakaian bahan aglomerat cukup besar. Selain itu dapat diketahui ada empat pola pemakaian bahan aglomerat pada candi-candi di Kawasan Prambanan, yaitu (I) pola pemakaian tetap, (II) pola pemakaian relatif merata, (III) pola pemakaian tidak merata, dan (IV) pola tidak digunakannya batu aglomerat.

Pola I batu aglomerat digunakan secara tetap pada bangunan pagar ketiga, khususnya untuk pondasi dan batu isian. Dari seluruh situs candi yang mempunyai pagar ketiga (Candi Lorojonggrang, Candi Sambisari dan Candi Se$w u^{15}$ ), semuanya menggunakan batu aglomerat untuk pondasi dan batu isiannya. Pola II merupakan pola pemakaian batu aglomerat tetap pada pondasi bangunan baik bangunan utama, bangunan serta, pagar keliling ke-1 dan pagar keliling ke-2, serta pripih. Pola III, batu aglomerat digunakan secara tidak merata, dipakai untuk batu kulit lantai candi, batu kulit bangunan serta, batu candi lepas dan beberapa arca. Pemakaian tersebut khususnya terdapat pada bangunan-bangunan serta di perbukitan Baturagung. Di dataran alu-vial atribut-atribut candi tersebut umumnya menggunakan batu andesit. Pola IV yaitu tidak digunakannya batu aglomerat baik pada batu kulit semua jenis bangunan candi maupun semua situs candi. Semua atribut tersebut menggunakan batu andesit.

bangunan tunggal, bila tidak ada bangunan lainnya dalam sebu-ah situs candi.

${ }^{14}$ Dimaksud bangunan serta adalah bangunan yang lebih kecil yang berdiri di sekitar bangunan utama dalam gugusan candi. Bangunan serta meliputi candi perwara, bangunan stupa, candi apit, "balai" dari bangunan "pendapa" Ratu Baka, dan bangunan-bangunan lainnya dalam gugusan percandian.

${ }^{15}$ Pagar keliling ketiga Candi Sewu ditemukan setelah penelitian saya selesai. Dengan bertambahnya bukti tersebut, ada keteraturan dalam penggunaan bahan bangunan untuk pagar keliling ketiga pada candican-di di daerah penelitian.
Hasil penelitian menunjukkan adanya pertimbangan ekologi dalam pemilihan dan penggunaan bahan bangunan candi. Berdasarkan sebagaian besar situs candi menggunakan batu aglomerat, menunjukkan bahwa bahan tersebut menjadi sumberdaya budaya sebatas kemampuan yang dapat dimanfaatkannya (culturally defined resources). Batu andesit mutlak digunakan untuk batu kulit candi dan yoni (seluruhnya ada? situs candi yang memiliki yoni). Batu aglomerat digunakan sebagai bahan alternatif karena lingkungan menyediakannya. Dengan kata lain, penggunaan batu aglomerat merupakan hasil adaptasi kebudayaan dengari lingkungannya

Candi-candi yang terdapat di perbukitan $\mathrm{Ba}$ turagung seperti Candi ljo, Candi Barong dan Gapura dan Keraton Ratuboko, menggunakan batu andesit untuk batu kulit bangunan utama. Yoniyoni yang berasal dari perbukitan Baturagung, seperti di Situs Semarangan, Miri, Barong, mengunakan andesit. Tentunya dalam membangun candi-candi tersebut manusia masa lalu harus turunnaik ke lokasi untuk mencari batuan andesit dari berbagai penjuru. Mengapa tidak menggunakan bahan aglomerat dimana sumbernya tersedia melimpah? Dilihat dari segi minimisasi enerji dan maksimisasi hasil kerja, penggunaan batu andesit untuk candi-candi di perbukitan Baturagung tidaklah ekonomis. Penggunaan batu andesit untuk candi-candi di dataran Baturagung, didasarkan pada analisis kontekstual.

\section{Penutup}

Hasil penelitian arkeologi-ruang yang telah diuraikan di atas, pada satu sisi memberikan buktı bahwa pendirian bangunan suci tidak lepas dari proses sistemik. Pemolaan keruangan dari situssitus arkeologi dapat mencerminkan pemo-laan aktivitas manusia masa lalu (Mundardjito 1993b:17). Akan tetapi pendekatan dan pandangan sistemik ini tidak dapat menjelaskan seluruh aspek budaya yang melatari penempatan dan pendirian bangunan suci. Sejumlah kecil situs candi tidak mengikuti pertimbangan ekologi sesuai dengan aturan-aturan pendirian bangunan suci dari kitab India kuno; dan pemakaian batu andesit pada candi-candi yang berada di lokasi sumber batu aglomerat, mengharuskan mencoba melihat dari konteks yang lain.

Hal semacam itu telah lama disadari oleh lan Hodder, bahwa penjelasan-penjelasan siste-mik adaptif dan materialistik tidak mampu me-nembus dimensi-dimensi budaya yang lain, teru-tama yang bersifat idealistik dan simbolik (Tanu-dirjo,1993) la menekankan peran individu, gaga-san internal, dan aspek sejarah ikut memainkan peran aktif dalam sistem buidaya. 
Pembahasan mengenai candi dan konteksnya dalam makalah ini, memberi peluang untuk menafsirkan budaya bendawi masa lalu tersebut dari segi epistimologi "menerangkan" (enklaren), maupun "memahami" (versthehen). Dari epistemologi enklaren, arkeologi dikembangkan sebagai science (ilmu pengetahuan alam) yang erat hubungannya dengan "hukum ${ }^{16 "}$ ". "prediksi" dan "obyektivitas". Enklaren menerangkan keteraturan dengan penyebabnya, tetapi bukan hakekat penyebabnya. Di lain fihak, arkeologi dipandang sebagai ilmu humaniora atau ilmu pengetahuan budaya, yang berusaha untuk mengerti berbagai unsur berkenaan dengan data (Noerhadi Magetsari 1986:95). Menurut pendapat mereka, tidak mungkin menerapkan metode yang sama atas obyek penelitian yang berbeda hakekat. Metode yang dikembangkan secara khusus adalah metode hermeneutik yang menekankan kajiannya pada pengungkapan makna teks dan amanat pengarangnya (rekonstruksi makna). Dari metode hermeneutik ini dikembangkan interpretasi yang didasarkan atas "emphaty' terhadap teks ke arah interpretasi teks secara umum. Untuk mengatasi jarak budaya dan waktu antara peneliti dan teks yang ditelitinya, dikembangkan metode "lingkaran heurmenetik", didasarkan pada konsep adanya hubungan melingkar antara pemahaman bagian dengan keseluruhan, bagai kata dengan kalimat atau serangkaian kalimat (Noerhadi Magetsari 1986:97).

Soekmono (1974) dan Noerhadi Magetsari (1982) merupakan peneliti yang berupaya memahami makna candi dengan menggunakan meto-de dari ilmu pengetahuan budaya, sebagaimana peneliti-peneliti candi sebelumnya. Mundardjito (1993) membuka perspektif baru dengan menggunakan pendekatan arkeologi-ekologi. Penelitiannya dilandasi pandangan sistemik dengan menggunakan ilmu-ilmu bantu dari ilmu pengetahuan alam, seperti geografi, ekologi, dan statis-tikmatematik. Penelitian yang dilakukannya dikembangkan dari teori dan metodologi Arkeologi Pembaharuan

Perubahan tersebut membawa pandangan post-processual archaeology ke dunia arkeologi Indonesia baru-baru ini. Postprocessual archaeology berupaya menggabungkan metodologi her-

16 Pengertian hukum dalam ilmu pengetahuan alam me-ngandung sifat kausal yang dicapai melalui pengama-tan atas fenomena. Dari pengamatan dikenali adanya keteraturan-keteraturan. Selanjutnya dicari "penye-bab" terjadinya keteraturan-keteraturan itu. "Penye-bab" itulah yang dicoba untuk "diterangkan" yang me-nyangkut hubungan antar fenomena melalui penga-matan empiris (Noerhadi Magetsari 1986:92-93). meneutik dan metode dari ilmu pengetahuan alam. Ian Hodder berupaya menterjemahkan budaya bendawi masa lalu sebagai proses sistemik dan simbolik. Makalah ini memberi peluang un-tuk "menerangkan" dan "memahami" candi seca-ra kontekstual.

\section{KEPUSTAKAAN}

Gibbon, Guy. 1989. Explanation in Archaeology Oxford:Basil Blackwell Ltd

Hodder, lan. 1985. Postprocessual Archaeology dalam Advances in Archaeological Me-thod and Theory, Vol. 8 (ed. Michael B. Schiffer). New York: Academic Press.

1986.Reading the Past: Current Approach to Interpretation in Archaeology. Cam-bridge: Cambridge University Press

Mundardjito.1993a.Kecenderungan Penelitian Arkeologi Dunia Mutakhir. dalam EHPA Yogya Kaliurang 25-30 Juli 1993

.1993b.Pertimbangan Ekologi Dalam Penempatan Situs Masa Hindu-Buda di Daerah Yogyakarta: Kajian Arkeologi-Ruang Skala Makro. Disertasi, Jakarta: UI

Noerhadi,Magetsari., 1986. Pengertian "Menerangkan" (Enklaren) dan "Mengerti" (Versthehen) dalam Arkeologi: Suatu Permasalahan Arkeologi Sebagai IImu, dalam PIA IV, Cipanas 3-9 Maret 1986, Jakarta:Puslit Arkenas

1995. Metode Penelitian Agama dalam Arkeologi, dalam Seminar Nasional Riset Arkeologi, Depok: Fakultas Sastra Universitas Indonesia, tanggal 23-24 Januari 1995.

Rangkuti,Nurhadi.1984.Pemakaian Batu Tufa pada Candi-candi di Sekitar Prambanan Skripsi. Jakarta:Fak. Sastra Universitas indonesia.

Soekmono,R.1974.Candi, Fungsi dan Pengertiannya Dissertasi Jakarta:UI.

Tanudirjo,Daud Aris.1993. Arkeologi Indonesia Masa Depan: Unilinearisme atau Multilinerisme?. EHPA: Yogyakarta:Kaliurang 25-30 Juli. 